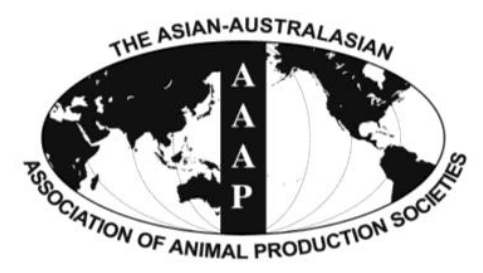

Asian-Aust. J. Anim. Sci.

Vol. 25, No. $5: 690$ - 700

May 2012

www.ajas.info

http://dx.doi.org/10.5713/ajas.2011.11451

\title{
Bacterial Community Dynamics during Swine In vitro Fermentation Using Starch as a Substrate with Different Feed Additives for Odor Reduction
}

\author{
Md. J. Alam ${ }^{1,2}$, C. D. Jeong ${ }^{1}$, L. L. Mamuad ${ }^{1}$, H. G. Sung ${ }^{3}$, D. W. Kim ${ }^{4}$, S. B. Cho ${ }^{5}$, \\ K. Lee ${ }^{6}$, C. O. Jeon ${ }^{7}$ and Sang S. Lee ${ }^{1, *}$ \\ ${ }^{1}$ Ruminant Nutrition and Anaerobe Laboratory, Department of Animal Science and Technology, \\ Sunchon National University, Suncheon, Jeonnam 540-742, Korea
}

\begin{abstract}
The experiment was conducted by in vitro fermentation and bacterial community analysis to investigate the reduction of odorous compounds in response to the use of feed additives (FA) during carbohydrate overload in growing pigs. Soluble starch at $1 \%$ (control) and various FA at $0.1 \%$ Ginseng meal (FA1); Persimmon leaf (FA2); Gingko nut (FA3) and Oregano lippia (FA4) were added to fecal slurry and incubated anaerobically for 12 and $24 \mathrm{~h}$. In vitro parameters and microbial diversity of the dominant bacteria following fermentation were analyzed using Denaturing Gradient Gel Electrophoresis (DGGE), band cloning and sequencing of the V3 region. Results showed that total gas production increased with the advancement of incubation ( $\mathrm{p}<0.05)$. $\mathrm{pH}$ values of FAs and control groups were decreased except the FA4 group which increased somewhat from 12 to $24 \mathrm{~h}(\mathrm{p}<0.05)$. Ammonia nitrogen $\left(\mathrm{NH}_{3}-\mathrm{N}\right)$ and $\mathrm{H}_{2} \mathrm{~S}$ gas concentrations were comparatively lower in both stages in FA4 treatment than in the other groups $(\mathrm{p}<0.05)$. Hence, $\mathrm{NH}_{3}-\mathrm{N}$ concentrations in liquid phases were increased $(\mathrm{p}<0.05)$ from 12 to $24 \mathrm{~h}$, but the trend was lowest in FA4 than in the other groups at both stages. The total VFA production was comparatively lower and butyrate levels were moderate in FA4 group than in the the other groups during both stages $(\mathrm{p}<0.05)$. Indirect odor-reducing compounds such as $\mathrm{NO}_{2}, \mathrm{NO}_{3}$ and $\mathrm{SO}_{4}$ concentrations were higher in the FA4 and FA3 than in the other groups at $24 \mathrm{~h}(\mathrm{p}<0.05)$. After fermentation, ten dominant bands appeared, six of which appeared in all samples and four in only the FA4 treated group. The total number of DGGE bands and diversity was higher in the FA4-group compared to other groups. Additionally, similarity indices were lowest (71\%) in the FA4, which represented a different bacterial community compared with the other groups. These findings indicate that $\mathrm{NH}_{3}-\mathrm{N}, \mathrm{H}_{2} \mathrm{~S}$ and VFA production was minimal, and $\mathrm{pH}$ was also better in the FA4 group than in the other groups. Furthermore, the conversion of odor-reducing indirect compounds or their intermediates was higher in the FA4 group in compared to the other groups. FA4 group generated less odorous products and more indirect products by in vitro fermentation at $24 \mathrm{~h}$, and their microbial pattern appeared to differ from that of the other groups. These findings suggest that this particular FA could change the microbial population, which may have a beneficial effect on odor reduction. It is recommended that the oregano lippia may be supplied to growing pigs as FA along with excess carbohydrate sources to reduce the production of odorous compounds. (Key Words: Bacterial Community, Starch, Feed Additives, In vitro Fermentation, Odor Reduction)
\end{abstract}

\footnotetext{
* Corresponding Author: Sang Suk Lee. Tel: +82-10-277-61-187, Fax: +82-61-750-3237, E-mail: rumen@ scnu.kr

2 Department of Animal Science, Sher-e-Bangla Agricultural University, Dhaka-1207, Bangladesh.

${ }^{3}$ Adbiotech Co. Ltd., Chun-Cheon City 200-880, Korea.

${ }^{4}$ Swine Science Division, National Institute of Animal Science, RDA, Cheonan, 330-801, Korea.

5 Animal Environment Division, National Institute of Animal Science, RDA, Suwon, 441-706, Korea.

${ }^{6}$ Department of Animal Sciences, Ohio State University, 2029 Fyffe Road, Columbus, OH 43210, USA.

${ }^{7}$ Department of Life Science, Chung-Ang University, Seoul, 156756, Korea.
}

Submitted Nov. 27, 2011; Accepted Feb. 14, 2012; Revised Mar. 28, 2012

\section{INTRODUCTION}

The large intestine in the pig provides a chamber for the final phase of digestion, and this digestive function principally involves the breakdown of carbohydrates and proteins by microbes under anaerobic conditions to different gases, such as short chain fatty acids (SCFA) (Cummings and Macfarlane, 1991). Incomplete fermentation of proteins and other nutrients entering the large intestine causes a complex mixture of malodorous substances (Miner, 1977; Mackie et al., 1998; Ritter, 1989). Jensen and Hansen (2006) found that the predominant formation of malodorous substances occurs in the large 
intestine due to microbial degradation of several substrates. However, if the level of carbohydrate availability is increased for microbial fermentation, then proteinfermentative end products are reduced (O'Connell et al., 2005). Moreover, fermentation of carbohydrates in the hindgut has been recognized as one of the primary events leading to odor in the pig (Wang et al., 2004) and enriched fermentable $\mathrm{CHO}$ have been found to induce significantly higher diversities of bands in the colonic microflora of pigs (Konstantinov et al., 2004). Therefore, the effects of carbohydrates (starch) as a substrate on the formation of odors were investigated. Preliminary concentration studies were conducted to examine the effects of various carbohydrate concentrations $(0.25$ to $5 \mathrm{~g} / 100 \mathrm{ml})$ on cecal fermentation as measured by changes in $\mathrm{pH}$, and $1 \mathrm{~g} / 100 \mathrm{ml}$ of starch was found to be sufficient to produce the maximum effects (Bailey et al., 2002). Therefore, $1 \mathrm{~g}$ starch/100 ml was taken as carbohydrate overload in this experiment.

FAs in swine diets enhance odor reduction via antioxidative and antimicrobial actions and beneficial effects on palatability and gut functions (Windisch et al., 2008). In addition, FAs are one of the biochemical and chemical agents that can reduce odor from animal production facilities (Ritter, 1989). Identification of suitable FAs and nutrients that enhance beneficial microbial communities is essential (Hume et al., 2006; Parker et al., 2007). Indeed, manipulation of the gut microbial community by FAs may help reduce the environmental impact of swine production (Oviedo-Rondón, 2009). Accordingly, the present investigation, in a first aspect relates to FAs that will able to reduce the generation of feces odor by decreasing the amount of at least one of the compounds selected from a group consisting of: i) sulphide compounds; ii) ammonia; iii) VFA. It was thought that FAs supplements in the presence of excess carbohydrate may modify microbial fermentation to reduce odorous compounds in the pig.

DNA fingerprinting techniques such as DGGE (Konstantinov et al., 2003; Zhu et al., 2003) can be used to describe the microbial diversity of a variety of ecosystems in intestinal microbiota (Felske et al., 1998; Muyzer et al., 1993; Muyzer and Smalla, 1998). It has been suggested that application of such techniques could be used in combination with in vitro fermentation as a preliminary test to study shifts in microbial populations exposed to a single source of fermentable carbohydrate as a source of energy. Carbohydrate included in feed may exert an important influence on the large intestine bacterial community since it is not digested by small intestinal enzymes, but reaches the hindgut for fermentation by microorganisms. Therefore, a PCR-DGGE approach was used to reveal bacterial changes following in vitro fermentation by examining the microbial ecosystem in the large intestine and feces of pigs provided with various FAs along with a soluble starch as a carbohydrate source. However, one approach to investigate the problem of odor with the above conditions is to use animal models in conjunction with an in vitro fermentation method.

The overall objective of the present study was to determine the excretion of major odor causing and reducing compounds in response to different FAs by in vitro fermentation and to examine the effect of these additives on bacterial communities when $\mathrm{CHO}$ is available (overloaded) in the large intestine of growing finishing pigs. Moreover, cloning and sequencing of the DGGE bands were used to identify which bacteria was enriched during fermentation of these FAs in carbohydrate while reducing odor in the process.

\section{MATERIALS AND METHODS}

\section{Animals, facilities and experimental design}

The pigs used in this study were selected from a commercial herd, and were the progeny of a Landracex Yorkshire sow and a Duroc sire. The experimental samples were collected from a total of 9 sixth month old castrated pigs with a live weight of $95 \pm 5 \mathrm{~kg}$. The experiment was conducted in the Laboratory of Microbiology and Biotechnology under the Department of Animal Science and Technology at Sunchon National University (SCNU), Republic of Korea. The experimental proposals and procedures for the care and treatment of the pigs were approved by the Animal Care Committee of SCNU. The animals were housed at the SCNU research farm which was well equipped with water, feed, and disposal systems, and individual pens $(12.7 \mathrm{~cm} \times 7.6 \mathrm{~cm})$ with fully slatted floors. The diets were fed to the pigs as mash ad libitum in the experimental period. The nutrient composition of the basal diet was in accordance with the suggestions of the nutrient requirements for swine from NRC (1998) are shown in Table 1. Serum bottles were inoculated with $100 \mathrm{ml}$ of $10 \%$ fecal slurry, $1 \%$ soluble starch and $0.1 \%(0.1 \mathrm{~g}$ or $0.1 \mathrm{ml})$ of different FAs except for the control (con), which did not contain FA. The FA treatments were as follows: ginseng meal powder (FA1), persimmon leaf powder (FA2), gingko nut powder (FA3), and oregano lippia (OL) (FA4). The serum bottles were incubated under anaerobic conditions to microbial fermentation for 12 and $24 \mathrm{~h}$. All treatments and Con were replicated in three. Total gas production, $\mathrm{pH}$, $\mathrm{NH}_{3}-\mathrm{N}$ (gas and liquid phase), $\mathrm{H}_{2} \mathrm{~S}$, VFA and lactate at 12 and $24 \mathrm{~h}$, and $\mathrm{NO}_{2}, \mathrm{NO}_{3}$ and $\mathrm{SO}_{4}$ concentrations at $24 \mathrm{~h}$ were measured. In addition, the microbial communities were analyzed by PCR-DGGE after $24 \mathrm{~h}$ of in vitro 
Table 1. Formula and chemical composition of basal diet for the grower-finishing pigs (as fed basis)

\begin{tabular}{|c|c|}
\hline Ingredients/nutrients & Amount $(\mathrm{g} / \mathrm{kg})$ \\
\hline \multicolumn{2}{|l|}{ Diet composition } \\
\hline Yellow corn & 451.5 \\
\hline Wheat & 250.00 \\
\hline Wheat bran & 40.00 \\
\hline Soybean meal & 160.00 \\
\hline Limestone & 78 \\
\hline Calcium phosphate & 11.0 \\
\hline Salt & 2.5 \\
\hline Vit.-min. premix ${ }^{1}$ & 5.5 \\
\hline Animal fat & 25.0 \\
\hline Molasses & 45.0 \\
\hline L-lysine & 1.7 \\
\hline \multicolumn{2}{|l|}{ Chemical composition $^{2}$} \\
\hline $\mathrm{ME}(\mathrm{MJ} / \mathrm{kg})$ & 13.66 \\
\hline Crude protein & 160.0 \\
\hline $\mathrm{Ca}$ & 5.0 \\
\hline Available P & 4.5 \\
\hline Lysine & 8.0 \\
\hline Methionine & 2.7 \\
\hline \multicolumn{2}{|c|}{$\begin{array}{l}{ }^{1} \text { Per kg vit-min. premix provided the following nutrients: vitamin } \mathrm{A} \text {, } \\
6,000 \mathrm{IU} \text {; vit } \mathrm{D}_{3}, 800 \mathrm{IU} \text {; vit } \mathrm{E}, 20 \mathrm{IU} \text {; vit } \mathrm{K}_{3}, 2 \mathrm{mg} \text {; thiamin, } 2 \mathrm{mg} \text {; } \\
\text { riboflavin, } 4 \mathrm{mg} \text {; vit } \mathrm{B}_{6}, 2 \mathrm{mg} \text {; vit } \mathrm{B}_{12}, 1 \mathrm{mg} \text {; pantothenic acid, } 11 \mathrm{mg} \text {; } \\
\text { niacin, } 10 \mathrm{mg} \text {; biotin, } 0.02 \mathrm{mg} \text {; } \mathrm{CuSO}_{4}, 21 \mathrm{mg} ; \mathrm{FeSO}_{4}, 100 \mathrm{mg} ; \mathrm{ZnSO}_{4} \text {, } \\
60 \mathrm{mg} ; \mathrm{MnSO}_{4}, 90 \mathrm{mg} ; \mathrm{CaIO}_{4}, 1.0 \mathrm{mg} ; \mathrm{CoNO}_{3}, 0.3 \mathrm{mg} \text {; } \mathrm{NaSe}, 0.3 \mathrm{mg} \text {. } \\
{ }^{2} \text { Calculated value. }\end{array}$} \\
\hline
\end{tabular}

fermentation as described below.

\section{Salt media and in vitro model}

The ingredients were added per liter of distilled water to prepare the sterile salt media $\left(5 \mathrm{~g} \mathrm{NaHCO}_{3}, 0.9 \mathrm{~g} \mathrm{NaCl}, 0.9\right.$ $\mathrm{g}\left(\mathrm{NH}_{4}\right)_{2} \mathrm{SO}_{4}, 0.45 \mathrm{~g} \mathrm{KH}_{2} \mathrm{PO}_{4}, 0.45 \mathrm{~g} \mathrm{~K}_{2} \mathrm{HPO}_{4} \cdot 3 \mathrm{H}_{2} \mathrm{O}, 0.03 \mathrm{~g}$ $\mathrm{CaCl}_{2} \cdot 2 \mathrm{H}_{2} \mathrm{O}, 0.02 \mathrm{~g} \mathrm{MgCl}_{2}, 0.01 \mathrm{~g} \mathrm{MnSO}_{4} \cdot 4 \mathrm{H}_{2} \mathrm{O}, 0.01 \mathrm{~g}$ $\mathrm{CoCl}_{2} \cdot 6 \mathrm{H}_{2} \mathrm{O}, 0.01 \mathrm{~g} \mathrm{FeSO}_{4} \cdot 7 \mathrm{H}_{2} \mathrm{O}$ and $0.25 \mathrm{~g}$ Cysteine) according to the methods described by (Jensen et al., 1995; Wang et al., 2004). The $\mathrm{pH}$ of the media was adjusted to $6 \pm 0.3$ and it was then autoclaved $\left(1 \mathrm{~atm}, 121^{\circ} \mathrm{C}, 15 \mathrm{~min}\right)$ for sterilization. Fresh feces was collected directly from the anus of the pigs and transferred in a thermo flask at $37^{\circ} \mathrm{C}$ under vacuum conditions prior to starting the experiment. The pigs behaved normally and remained in good health during the experimental fecal collection, which was generally completed within $15 \mathrm{~min}$ to avoid contamination. Collected feces were inoculated at $10 \%(\mathrm{w} / \mathrm{v})$ into the salt media under a constant flow of $\mathrm{CO}_{2}$ (Wang et al., 2004). The prepared suspension was then transferred to a $\mathrm{CO}_{2-}$ flushed sterile plastic bag and homogenized for $2 \mathrm{~min}$. The resulting homogenate was subsequently filtered through 4fold sterile cheese cloth to remove crude particulates, after which were constant $\mathrm{CO}_{2}$-flushed into an anaerobic system for $30 \mathrm{~min}$. Sterile serum bottles $(160 \mathrm{ml})$ were then filled with $100 \mathrm{ml}$ of the prepared $\mathrm{O}_{2}$-free slurry. One gram soluble starch and $0.1 \mathrm{~g}$ or $\mathrm{ml}$ of the FAs (Research Institute, DAEHO Co. Ltd., Korea) were then added to the bottles. Immediately after addition, the gas phase of each serum bottle was changed to $\mathrm{O}_{2}$-free $\mathrm{CO}_{2}$ by three successive cycles of evacuation and refilling with $\mathrm{CO}_{2}$ using a manifold connected to a vacuum pump and a cylinder of $\mathrm{CO}_{2}$ in the anaerobic gassing system. The bottles were then sealed with sterile butyl rubber stoppers that were kept in place with metal screw caps. The filled serum bottles were subsequently placed in a HB-201SF shaking incubator (HANBAEK Scientific Co., Korea) set at $50 \mathrm{rpm}$ and $37^{\circ} \mathrm{C}$ in anaerobic incubations for 12 and $24 \mathrm{~h}$. Odorous compounds and DGGE analysis were performed following completion of the incubation periods.

Analysis for odor compounds after in vitro fermentation

Total gas production by each of the serum bottle was measured using press and sensor machine (Laurel Electronics, Inc., Costa Mesa, CA 92626, USA) at different stages. The gas measurement was conducted in pounds per square inch (PSI), after which it was converted into $\mathrm{ml}$ using the following equation: $\mathrm{y}=0.023 \mathrm{x}+0.055$ and standard: $\mathrm{R}^{2}=0.996$. A Multi-Gas Monitor, PGM-7800 (RAE Systems Inc., 1339 Moffett Park Drive, Sunnyvale, CA, USA) was used to determine ammonia and hydrogen sulfide in gas phase at both stages before sampling for other analyses. The $\mathrm{pH}$ value was measured using a Pinnacle series M530p meter (Schott instruments D-55122 Mainz, Germany) after each of the bottles was uncapped and fermentation was stopped by swirling the bottles on ice at different stages. The remainders of the fermenta contents were then preserved at $-20^{\circ} \mathrm{C}$ until analysis. At the time of testing, the samples were centrifuged at $890 \times \mathrm{g}$ at $4^{\circ} \mathrm{C}$ for 15 min prior to analysis for ammonia nitrogen in the liquid phase using a Micro 17TR High Speed Centrifuge (Hanil Science Industrial Co. Ltd., Guwangju, Korea) and then passed through a $0.2 \mu \mathrm{m}$ Millipore filter. The ammonia concentration was measured based on the optical density (OD) at $630 \mathrm{~nm}$, which was measured using a Libra S22 spectrophotometer (Biochrom Ltd., CB40FJ, England) according to the method described by (Chaney and Marbach, 1962). The OD was determined for each sample and the values of $\mathrm{NH}_{3}-\mathrm{N}$ were then calculated using the equation developed from standard solution: $y=0.0004 x+0.0002$ and a standard of $\mathrm{R}^{2}=0.9998$. The VFA (acetate, propionate, butyrate and formate) and lactate concentrations were measured by HPLC (Agilent Technologies 1200 series, Germany) according to the methods described by (Tabaru et al., 1988; Han et al., 2005). An HPLC Varian Meta Carb $87 \mathrm{H}$ column $(300 \times 7.8 \mathrm{~mm}$; Agilent, Germany) was used. Samples were centrifuged at $16,609 \times \mathrm{g}$ for $5 \mathrm{~min}$ at $4^{\circ} \mathrm{C}$, 
filtered through $0.2-\mu \mathrm{m}$ Millipore filters and a standard was made at $0.999\left(\mathrm{R}^{2}\right)$ before analysis.

\section{Analysis of indirect compounds}

Fermented samples (preserved) were centrifuged at $890 \times \mathrm{g}$ for $15 \mathrm{~min}$ at $4^{\circ} \mathrm{C}$ and the supernatants were then filtered through $0.2-\mu \mathrm{m}$ cellulose acetate filters. The filtered supernatants were then used for analysis of nitrite, nitrate and sulfate. The nitrite- $\mathrm{N}$ concentration was determined using a Griess reagent kit (G-7921, Molecular Probes (2003)) according to manufacturer's method. The developed nitrite standard and equation were $\mathrm{R}^{2}=0.9989$ and $\mathrm{y}=$ $0.1748 x+0.0051$, respectively. The absorbance of the nitrite was determined using the OD at $548 \mathrm{~nm}$ against reference with aforementioned equation. The nitrate concentration was measured based on the OD at $410 \mathrm{~nm}$ following the modified method described by (Jenkins and Medsker, 1964). The OD values were calculated from the equation developed from standard solution $y=0.005 x-0.0057\left(R^{2}=\right.$ 0.9973 ) and values were expressed as $\mathrm{mg} \mathrm{NO}_{3}-\mathrm{N} / \mathrm{L}$. For determination of the sulfate concentration, the modified turbidimetric method conducted according to the method described by (Kolmert et al., 2000) with absorbance at 420 $\mathrm{nm}$. For calculation, the OD values were fitted with an equation, $y=0.0032 x+0.0043$ and standard, $R^{2}=0.9911$ to obtain an accurate sulfate concentrations.

\section{Microbiological analysis}

DNA extraction: The incubated preserved $\left(-20^{\circ} \mathrm{C}\right)$ samples $(1 \mathrm{ml})$ were used for genomic DNA extraction with Wizard Genomic DNA Purification Kits (Promega, USA). The extracted DNA was then subjected to electrophoresis on a $0.7 \%$ agarose gel $(\mathrm{W} / \mathrm{V})$ containing gel red to estimate the amount and integrity of the DNA products $(23 \mathrm{~kb})$, and visualized using UV light with a Gel Logic 200 Imaging System (Eastman KODAK Company, Rochester, NY, USA).

$16 S$ rDNA amplification: Amplicons of 16S rDNA were amplified using the general polymerase chain reaction (PCR). PCR primers 27F (5'-AGAGTTTGATCMTGG CTCAG-3') and 1492R (5'-GGYTACCTTGTTACGACTT$3^{\prime}$ ) were used to amplify the segment of eubacterial $16 \mathrm{~S}$ rDNA from nucleotide 27 to 1,492 (Nübel et al., 1996). PCR was conducted using a Taq DNA Polymerase Kits (Promega, USA) in reaction mixtures with a final volume of $50 \mu \mathrm{l}$ that contained $10 \mathrm{mM}$ Tris- $\mathrm{HCl}, 50 \mathrm{mM} \mathrm{KCl}, 1.5 \mathrm{mM}$ $\mathrm{MgCl}_{2}, 200 \eta \mathrm{M}$ dNTP, 25 pmol of each primer, $0.5 \mathrm{U}$ of Taq DNA polymerase and 10 to 50 ๆg of DNA. PCR was conducted using a Gene Amp C1000 ${ }^{\mathrm{TM}}$ PCR System (BioRad Laboratories, Inc, Hercules, CA, USA). The thermal cycle was performed using the following conditions: initial denaturation at $94^{\circ} \mathrm{C}$ for $5 \mathrm{~min}$, followed by 32 cycles of $94^{\circ} \mathrm{C}$ for $45 \mathrm{~s}, 65^{\circ} \mathrm{C}$ for $45 \mathrm{~s}$ and $72^{\circ} \mathrm{C}$ for $1 \mathrm{~min}$, with a final extension at $72^{\circ} \mathrm{C}$ for $10 \mathrm{~min}$. The products were then analyzed by electrophoresis on (1\%) agarose gel to assess the sizes $(1.5 \mathrm{~kb})$ and amounts (Zhu et al., 2003).

\section{DGGE- PCR condition}

The following primers with a GC clamp for forward were used to amplify the V3 region of the bacterial $16 \mathrm{~S}$ rDNA amplicons for nested-touchdown PCR: 341F-GC (5'CGCCCGCCGCGCGCGGCGGGCGGGGCGGGGGCAC GGGGGGCCTACGGGAGGCA GCAG-3') and 518R (5'ATTACCGCGGCKKGCTG-3') (Nübel et al., 1996). PCR was conducted using a Taq DNA Polymerase Kits (Promega, USA) and the same thermal cycler described above to subject the samples to touch-down PCR condition: 2 cycles of $94^{\circ} \mathrm{C}$ for $5 \mathrm{~min}, 94^{\circ} \mathrm{C}$ for $30 \mathrm{~s}, 65^{\circ} \mathrm{C}$ to $56^{\circ} \mathrm{C}$ (step-down) for $30 \mathrm{~s}$ and $72^{\circ} \mathrm{C}$ for $30 \mathrm{~s}$, followed by 10 cycles of $94^{\circ} \mathrm{C}$ for $30 \mathrm{~s}, 55^{\circ} \mathrm{C}$ for $30 \mathrm{~s}$ and $72^{\circ} \mathrm{C}$ for $30 \mathrm{~s}$, with a 7 -min final extension at $72^{\circ} \mathrm{C}$. Agarose gel (2\%) electrophoresis was then conducted to estimate the amount and integrity of the products (approximately $230 \mathrm{bp}$ ).

Denaturing gradient gel electrophoresis (DGGE) was conducted using a D-Code Universal Mutation Detection System (Bio-Rad, Hercules, CA, USA). Amplicons of the $\mathrm{V} 3$ region of the 16S rDNA were used for sequence-specific separation by DGGE according to the specifications of (Muyzer and Smalla, 1998). DGGE was performed on 8\% polyacrylamide gels containing $40 \%$ polyacrylamide bissolution (37:1) (Bio-Rad, USA), 50× TAE buffer (final conc. $1 \mathrm{X})$, urea $(7 \mathrm{M})$, formamide $(40 \%)$ and distilled water to generate a denaturant concentration (gel solution) of between $40 \%$ and 60\% (Denaturing Gradient Gel Electrophoresis (DGGE), 2004). As denaturing gradient, 7 $\mathrm{M} / \mathrm{L}$ urea and $40 \%(\mathrm{v} / \mathrm{v})$ formamide (Sigma, USA) were used. Electrophoresis was initiated in 7 to $8 \mathrm{~L}$ of $0.5 \mathrm{X}$ TAE buffer $(20 \mathrm{mmol} / \mathrm{L}$ Tris-acetate $(\mathrm{pH} 7.4), 10 \mathrm{mmol} / \mathrm{L}$ acetate, and $0.5 \mathrm{mmol} / \mathrm{L} \mathrm{Na} \mathrm{Na}_{2} \mathrm{EDTA}$ ] in the BioRad DGGE (D-code) system. The gel was subject to pre-running for $5 \mathrm{~min}$ at a voltage of $200 \mathrm{~V}$, and subsequently run at a fixed voltage of $60 \mathrm{~V}$ for $16 \mathrm{~h}$ at $60^{\circ} \mathrm{C}$ (Denaturing Gradient Gel Electrophoresis (DGGE), 2004). The gel was then stained with SYBR Green (Molecular Probes, Eugene, OR) at $10^{5}$ fold dilution in buffer $(0.5 \times \mathrm{TAE})$ for $15 \mathrm{~min}$ by slow shaking, and subsequently stained gel was diffused into the previously indicated buffer for $5 \mathrm{~min}$ (Morrison et al., 1998). The gels were then visualized for the bands by electrophoresis and prominent bands were cut through UVscanner.

\section{Similarity analysis and DNA elution of the DGGE gel}

The DGGE gel was scanned at 400 dpi and similarity indices were calculated for pairs of DGGE profiles from the densitometric curves of the scanned DGGE profiles using 
Molecular Analyst 1.12 software (Bio-Rad) based on the Pearson product-moment correlation coefficient (Häne et al., 1993). The gel containing 10 cloned 16S rDNA fragments (bands) were selected, marked, and cut by a UV visualization system for DNA elution. Small pieces of cut gel containing the bands were placed in $30 \mu \mathrm{DW}$ in eppendorf tubes and incubated overnight at $4^{\circ} \mathrm{C}$ to elute the DNA.

\section{Cloning of the gel eluted DNA products and sequence analysis}

One micro liter of the DGGE gel elutes were used as the template for PCR to amplify the bacterial $16 \mathrm{~S}$ rDNA using the $341 \mathrm{~F}$ (without GC clamp): (5'-CCTACGGGAGGCAG CAG-3') and 518R: (5'-ATTACCGCGGCT GCTGG-3') primers (Nübel et al., 1996) using the same method as described for the touchdown PCR above. The PCR products were then purified using a QIAquick PCR Purification Kits (Qiagen, Hilden, Germany) according to the manufacturer's instructions, after which the purified products were quantified (app. $200 \mathrm{bp}$ ) by electrophoresis on an agarose gel $(1.5 \%)$ containing gel red. The purified products were cloned in competent Escherichia coli JM109 cells (Takara Bio Inc, Otsu, Japan) using the Promega pGEM-T vector system according to the instructions of the manufacturer (Promega, Madison, WI). After transformants in LuriaBertani (LB) agar medium had grown $\left(37^{\circ} \mathrm{C}\right)$ overnight, blue-white screening for single-clone colonies of ampicillin (Sigma, St. Louis, MO, USA) resistant transformants (positive clones) were selected at random and transferred to LB broth medium, after which they were incubated at $37^{\circ} \mathrm{C}$ overnight. Next, $1.5 \mathrm{ml}$ aliquots of the cultures were subjected to plasmid DNA purification using QuickLyse Miniprep Kit 100 (Qiagen). The purified plasmids were then digested using ECoR 1 and 10x buffer (Takara Bio Inc), after which they were incubated at $37^{\circ} \mathrm{C}$ for $1 \mathrm{~h}$ to check the sizes ( $3 \mathrm{~kb}$ for plasmid vector and app. $200 \mathrm{bp}$ for DNA) using $1 \%$ agarose gel at electrophoresis.

Ten purified plasmid samples were sent to Macrogen,
Seoul, Korea for DNA sequencing. The obtained sequences were then compared to those available in the Gen-Bank database using a BLAST search and EzTaxon.

\section{Statistical analyses}

All data were subjected to statistical analysis in a completely randomized design using the general linear models (GLM) of SAS 9.1 (SAS, 2002). The effects of the FAs on total gas, $\mathrm{pH}, \mathrm{NH}_{3}-\mathrm{N}, \mathrm{H}_{2} \mathrm{~S}$, VFA, lactate, $\mathrm{NO}_{2}, \mathrm{NO}_{3}$ and $\mathrm{SO}_{4}$ concentrations were compared to the controls. Significant differences between treatments were further analyzed using Duncan's multiple comparison tests. Data reported are the mean values \pm standard error (SE) and $\mathrm{p}<0.05$ was considered to indicate significance.

\section{RESULTS AND DISCUSSION}

\section{Effect of FAs on odor compounds after fermentation}

The total gas production increased as the incubation period increased (Table 2). In addition, total gas production at both stages differed significantly among groups treated with different FAs $(\mathrm{p}<0.05)$. The total gas production observed in this study agreed with the findings reported by Robinson et al. (1989), who found that total gas production increased with incubation time due to increased microbial fermentation. The in vitro total gas production observed in the present experiment was also partially similar to the results obtained by (Patra et al., 2006), who found that total gas production as well as odorous compounds increased with time. However, an increase in gas production alone is not indicative of increased odor intensity; rather, the odorous compounds produced must be measured. Therefore, we evaluated the effects of different FA on these compounds.

The $\mathrm{pH}$ and concentrations of microbial metabolites in digesta have been used as indicators of intestinal health and microbial activity (Nyachoti et al., 2006). It has also been suggested that the optimum $\mathrm{pH}$ (6 to 7) is appropriate for microbial activity and fermentation. In the present study, the

Table 2. Total gas production and $\mathrm{pH}$ value from pig in vitro fermentation using soluble starch and FAs at different stages

\begin{tabular}{|c|c|c|c|c|c|}
\hline \multirow{2}{*}{ Incubation time $(\mathrm{h})$} & \multicolumn{5}{|c|}{ Treatment } \\
\hline & Control & FA1 & FA2 & FA3 & FA4 \\
\hline \multicolumn{6}{|c|}{ Total gas production $(\mathrm{ml} / 1 \mathrm{~g})^{1}$} \\
\hline $12 \mathrm{~h}$ & $63.33^{\mathrm{b}} \pm 0.88$ & $70.33^{\mathrm{a}} \pm 0.33$ & $70.33^{\mathrm{a}} \pm 0.33$ & $71.67^{\mathrm{a}} \pm 0.33$ & $60.33^{\mathrm{b}} \pm 0.33$ \\
\hline $24 \mathrm{~h}$ & $87.33^{\mathrm{b}} \pm 0.33$ & $84.67^{\mathrm{b}} \pm 0.33$ & $78.67^{\mathrm{bc}} \pm 0.33$ & $105.3^{\mathrm{a}} \pm 0.33$ & $71.0^{c} \pm 0.33$ \\
\hline \multicolumn{6}{|l|}{$\mathrm{pH}$ value } \\
\hline $12 \mathrm{~h}$ & $5.54^{\mathrm{c}} \pm 0.01$ & $5.40^{\mathrm{d}} \pm 0.003$ & $5.33^{\mathrm{e}} \pm 0.003$ & $5.63^{\mathrm{b}} \pm 0.003$ & $6.26^{\mathrm{a}} \pm 0.003$ \\
\hline $24 \mathrm{~h}$ & $5.26^{\mathrm{d} \pm 0.003}$ & $5.23^{\mathrm{d} \pm 0.01}$ & $5.32^{\mathrm{c}} \pm 0.003$ & $5.5^{\mathrm{b}} \pm 0.003$ & $6.62^{\mathrm{a}} \pm 0.003$ \\
\hline
\end{tabular}

Values are the mean \pm SE. means with different superscripts $\left({ }^{\mathrm{a}, \mathrm{b}, \mathrm{c}, \mathrm{d}, \mathrm{e}}\right)$ in the same row are significantly different $(\mathrm{p}<0.05)$. Control $=$ Salt media+feces $+1 \%$ soluble starch and FA1-FA4 = Inoculation with $0.1 \mathrm{~g}$ or $0.1 \mathrm{ml}$ of different FAs in fecal slurry and soluble starch; FA1 = Ginseng meal powder; FA2 = Persimmon leaf powder; FA3 = Gingko nut powder; FA4 = Oregano lippia (OL) oil extract.

${ }^{1}$ In the case of total gas production, the unit is milliliter per gram of dry matter substrate used for fermentation. 
$\mathrm{pH}$ of all of the treatments including the control decreased from 12 to $24 \mathrm{~h}$ except for that of FA4 group, which increased somewhat $(\mathrm{p}<0.05)$ (Table 2). Maintaining the proper acid-base balance and buffering capacity of the diet and the intestinal contents may influence the final $\mathrm{pH}$. In this study, the FA4 treated fermenta showed a slight increase in $\mathrm{pH}$ from 12 to $24 \mathrm{~h}$ compared to the other treatments and Con. Le et al. (2009) reported that a change in $\mathrm{pH}$ may also change the release of other odorous compounds such as $\mathrm{H}_{2} \mathrm{~S}$ and $\mathrm{NH}_{3}$. Furthermore, raising the $\mathrm{pH}$ of manure can attenuate the growth of odor-causing bacteria, thus reducing odor emissions (Zhu, 2000). Rainville and Morin (1985) also reported as it may one major reason that the raised $\mathrm{pH}$ could reduce odor is that it inhibits the growth of those odor-causing bacteria indigenous to swine manure. According to the above researches, it is evidenced from the present results that optimum $\mathrm{pH}$ (6 to 7) may be good for the intestinal health and microbial activity which is obtained in FA4 treatment. $\mathrm{pH}$ was also co-related to acid production during fermentation, which is discussed later.

The $\mathrm{NH}_{3}-\mathrm{N}$ concentration of the gas phases decreased from 12 to $24 \mathrm{~h}$ for all of the groups except for the FA4 group $(\mathrm{p}<0.05)$, in which it was not detected at either stage (Table 3). The lower $\mathrm{NH}_{3}-\mathrm{N}$ gas from 12 to $24 \mathrm{~h}$ may have been due to microbial modification and activity in response to FAs which affects more in FA4 group. On the other hand, $\mathrm{NH}_{3}-\mathrm{N}$ concentrations in the liquid phases were increased from 12 to $24 \mathrm{~h}$ of incubation, with the lowest concentration being observed for the FA4 treatment at $24 \mathrm{~h}(\mathrm{p}<0.05)$ (Table 3). Our findings indicated that ammonia-nitrogen concentration was reduced with some of the FA groups from 12 to $24 \mathrm{~h}$ of incubation after in vitro fermentation. Francis et al. (2002) found that saponin FA (from Yucca schidigera) reduced intestinal ammonia formation, which prevented health problem as well as environmental pollution from pig houses. Amon et al. (1995) also reported a $26 \%$ reduction in ammonia emission when fattening pigs were fed yucca extract. Some other investigations have also observed reduced ammonia emission after adding yucca extracts to pig diets (Colina et al., 2001; Cromwell, 1998). Killeen et al. (1998) confirmed that the existence of active components in extracts lowered or reduced intestinal urease activity and enzymes involved in the metabolic urea cycle. FA4-group reduced the concentrations of $\mathrm{NH}_{3}-\mathrm{N}$ in both the gas and liquid phases when compared to the other treatments and the Con. Although the results of the present experiment were not from the same additives to the previous findings but we confirmed the desired reduction of ammonia occurred with the additive FA4.

The $\mathrm{H}_{2} \mathrm{~S}$ concentrations in gas phases were very low in FA4 at $12 \mathrm{~h}$ and were completely absent at $24 \mathrm{~h}$ (Table 3 ). For the Con, FA1, FA2 and FA3, a large amount of $\mathrm{H}_{2} \mathrm{~S}$ was detected at $12 \mathrm{~h}$, while Con and FA1 showed higher, FA2 was lower and none was detected in FA3 at $24 \mathrm{~h}$ of incubation $(p<0.05)$. Fakhoury et al. (2000) found that hydrogen sulfide was highly correlated with malodorous sulphur compounds, which may be reduced by the selective addition of FAs to the diet. Moreover, Le et al. (2007) and Hayes et al. (2004) reported that odor emission was reduced by $80 \%$ when dietary carbohydrate was increased and protein decreased. In addition, Aarnink et al. (2005) reported that a change in $\mathrm{pH}$ may also change the release of other odorous compounds such as $\mathrm{H}_{2} \mathrm{~S}$. Furthermore, Gibson et al. (1988) stated that S-reducing bacteria may play an important role in the terminal stages of fermentation in the colon. Therefore, if the activity of S-producing bacteria can be inhibited and the activity of S-reducing bacteria can be increased by treatment with FAs, that may have the potential to reduce the concentration of odorous compounds. These opinions seem to supports the results observed in the present study.

Table 3. $\mathrm{NH}_{3}-\mathrm{N}$ concentration in gas and liquid phase, and $\mathrm{H}_{2} \mathrm{~S}$ concentration $(\mathrm{mg} / \mathrm{L})$ in gas phase from pig in vitro fermentation using soluble starch and FAs at different stages

\begin{tabular}{|c|c|c|c|c|c|}
\hline \multirow{2}{*}{ Incubation time (h) } & \multicolumn{5}{|c|}{ Treatment } \\
\hline & Control & FA1 & FA2 & FA3 & FA4 \\
\hline \multicolumn{6}{|c|}{$\mathrm{NH}_{3}-\mathrm{N}$ concentration in gas phase } \\
\hline $12 \mathrm{~h}$ & $200^{\mathrm{a}} \pm 0$ & $199.67^{\mathrm{a}} \pm 0.33$ & $78.33^{\mathrm{c}} \pm 0.33$ & $147^{\mathrm{b}} \pm 0.58$ & ND \\
\hline $24 \mathrm{~h}$ & $154^{\mathrm{a}} \pm 0$ & $65.33^{\mathrm{b}} \pm 0.33$ & ND & $29.67^{c} \pm 0.33$ & ND \\
\hline \multicolumn{6}{|c|}{$\mathrm{NH}_{3}-\mathrm{N}$ concentration in liquid phase } \\
\hline $12 \mathrm{~h}$ & $3.03^{\mathrm{a}} \pm 0.03$ & $3.56^{\mathrm{a}} \pm 0.33$ & $2.54^{\mathrm{b}} \pm 0.43$ & $2.75^{\mathrm{b}} \pm 0.15$ & $0.68^{\mathrm{c}} \pm 0.1$ \\
\hline $24 \mathrm{~h}$ & $3.27^{\mathrm{a}} \pm 0.25$ & $3.68^{\mathrm{a}} \pm 0.4$ & $3.06^{\mathrm{a}} \pm 0.44$ & $2.85^{\mathrm{b}} \pm 0.03$ & $0.88^{\mathrm{c}} \pm 0.05$ \\
\hline \multicolumn{6}{|c|}{$\mathrm{H}_{2} \mathrm{~S}$ concentration in gas phase } \\
\hline $12 \mathrm{~h}$ & $280.33^{\mathrm{b}} \pm 0.33$ & $291.3^{\mathrm{a}} \pm 0.33$ & $291.67^{\mathrm{a}} \pm 0.33$ & $291.675^{\mathrm{a}} \pm 0.33$ & $25.67^{\mathrm{c}} \pm 0.33$ \\
\hline $24 \mathrm{~h}$ & $288.67^{\mathrm{b}} \pm 0.33$ & $292.33^{\mathrm{a}} \pm 0.33$ & $19.33^{\mathrm{c}} \pm 0.33$ & ND & ND \\
\hline
\end{tabular}

Values are the mean \pm SE. Means with different superscripts $\left({ }^{\mathrm{a}, \mathrm{b}, \mathrm{c}}\right)$ in the same row are significantly different $(\mathrm{p}<0.05)$. Control $=$ Salt media+feces $+1 \%$ soluble starch and FA1-FA4 = Inoculation with $0.1 \mathrm{~g}$ or $0.1 \mathrm{ml}$ of different feed additives in fecal slurry and soluble starch; FA1 = Ginseng meal powder; FA2 $=$ Persimmon leaf powder; FA3 $=$ Gingko nut powder; FA4 $=$ Oregano lippia $(\mathrm{OL})$. 
Table 4. VFA and lactate production $(\mathrm{mg} / \mathrm{L})$ from pig in vitro fermentation using soluble starch and FAs at different stages

\begin{tabular}{|c|c|c|c|c|c|}
\hline \multirow{2}{*}{ Incubation time $(\mathrm{h})$} & \multicolumn{5}{|c|}{ Treatment } \\
\hline & Control & FA1 & FA2 & FA3 & FA4 \\
\hline \multicolumn{6}{|l|}{$12 \mathrm{~h}$ of incubation } \\
\hline Acetate & ND & ND & ND & ND & ND \\
\hline Propionate & $861.1^{\mathrm{a}} \pm 23.8$ & $100.3^{\mathrm{d}} \pm 11.4$ & $523.5^{\mathrm{b}} \pm 9.5$ & $877.9^{\mathrm{a}} \pm 77.1$ & $453.1^{\mathrm{c}} \pm 87.9$ \\
\hline Butyrate & $833.3^{\mathrm{d}} \pm 40.2$ & $651.2^{\mathrm{e}} \pm 44.1$ & $4,932.6^{\mathrm{a}} \pm 223.1$ & $3,577.2^{\mathrm{b}} \pm 282.51$ & $1,215.1^{\mathrm{c}} \pm 78.6$ \\
\hline Formate & ND & ND & ND & ND & ND \\
\hline Total VFA & $1,694.4^{\mathrm{c}} \pm 59.71$ & $1,581.1^{\mathrm{d}} \pm 35.0$ & $5,456.1^{\mathrm{a}} \pm 215.9$ & $4,455.1^{\mathrm{b}} \pm 121.9$ & $1,668.2^{c} \pm 114.3$ \\
\hline Lactate & $980.3^{\mathrm{a}} \pm 53.3$ & $600.8^{\mathrm{b}} \pm 4.8$ & $670.1^{\mathrm{b}} \pm 13.7$ & $999.2^{\mathrm{a}} \pm 185.2$ & $462.4^{c} \pm 89.0$ \\
\hline \multicolumn{6}{|l|}{$24 \mathrm{~h}$ of incubation } \\
\hline Acetate & ND & ND & ND & ND & ND \\
\hline Propionate & $1,030.6^{\mathrm{ab}} \pm 101.1$ & $1,278.1^{\mathrm{a}} \pm 102.1$ & $933.1^{\mathrm{b}} \pm 82.2$ & $1,243.2^{\mathrm{a}} \pm 92.6$ & $945.1^{\mathrm{b}} \pm 63.9$ \\
\hline Butyrate & $1,132.5^{\mathrm{c}} \pm 95.7$ & $1,598.7^{\mathrm{b}} \pm 123.2$ & $2,899.7^{\mathrm{a}} \pm 156.8$ & $3,102.1^{\mathrm{a}} \pm 264.4$ & $1,404.8^{\mathrm{b}} \pm 34.5$ \\
\hline Formate & ND & ND & ND & ND & ND \\
\hline Total VFA & $2,163.1^{\mathrm{d}} \pm 71.9$ & $2,876.8^{\mathrm{c}} \pm 85.0$ & $3,832.8^{\mathrm{b}} \pm 175.6$ & $4,345.3^{\mathrm{a}} \pm 184.2$ & $2,349.9^{\mathrm{d}} \pm 139.6$ \\
\hline Lactate & $1,712.2^{\mathrm{a}} \pm 98.9$ & $989.7^{\mathrm{bc}} \pm 67.7$ & $605.6^{\mathrm{d}} \pm 36.7$ & $1,021.3^{\mathrm{b}} \pm 79.2$ & $719.9^{c} \pm 46.7$ \\
\hline
\end{tabular}

Values are the mean \pm SE. ${ }^{\text {a,b,c,d,e }}$ Means within row with different superscripts differ $(\mathrm{p}<0.05)$.

$\mathrm{FA}=$ Feed additives as treatments; $\mathrm{ND}=$ Not detected $;$ Control $=$ Salt media + feces $+1 \%$ soluble starch and FA1-FA4 $=$ Inoculation with $0.1 \mathrm{~g}$ or $0.1 \mathrm{ml}$ of different FAs in facal slurry and soluble starch; FA1 = Ginseng meal powder; FA2 = Persimmon leaf powder; FA3 = Gingko nut powder; FA4 = Oregano lippia (OL).

The propionate was highest in FA1 followed by FA3, Con, FA4, and FA2 at $24 \mathrm{~h}$ of incubation $(\mathrm{p}<0.05)$ (Table 4$)$. The butyrate concentration was comparatively higher in the FA treatments than the Con, and FA4 showed moderate generation at $24 \mathrm{~h}$. The production of total VFA was comparatively lower in FA4 and Con than the other treatments at 12 and $24 \mathrm{~h}$ of incubation $(\mathrm{p}<0.05)$. Lactate production was highest in Con followed by FA3, FA1, FA4 and FA2 at $24 \mathrm{~h}$ of incubation $(\mathrm{p}<0.05)$. The total VFA concentrations were reduced and lactate production increased from 12 to $24 \mathrm{~h}$ incubation. In case of the maximum VFAs and lactate, FA4 treatment showed comparatively moderate concentrations than that of the other treatment groups and Con at $24 \mathrm{~h}$ of incubation (Table 4). Aarnink et al. (2005) found that VFA and lactate were the products of bacterial fermentation of carbohydrate residues in the large intestine. However, this carbohydrate fermentation depends on microbial activity, which may be modified by antimicrobial FAs. Mackie et al. (1998) reported that the production of some of the most offensive
VFAs can be reduced by increasing carbohydrate fermentation and limiting protein fermentation in the large intestine. van Beers-Schreurs et al. (1998) showed that the quantity of VFA and lactate production depends on the amount and composition of the substrate and the type of microbes present in the cecum. The results of the present study showed that if FAs were added with easily digestible carbohydrate, then VFA will be moderate in the large intestine (LI) to reduce the odor and other odor compounds. Taken together, the results of previous studies and the present study suggest that excess carbohydrate in the diet creates more odorous compound, but if some FA is added with soluble carbohydrate, it can moderate VFA as well as the odor. In the present experiment, FA4 treated fermenta had the optimum $\mathrm{pH}$ when compared to the other groups.

\section{Effect of indirect compounds by FAs on odor reduction}

Nitrite concentration was highest in FA4-group, while it was similar in Con, FA2 and FA3, and lowest in FA1-group $(\mathrm{p}<0.05)$ (Table 5) at $24 \mathrm{~h}$. Overall, the nitrate concentration

Table 5. Nitrite, nitrate and sulfate concentration (mg/L) from pig in vitro fermentation using soluble starch and FAs at $24 \mathrm{~h}$

\begin{tabular}{lccccc}
\hline \multirow{2}{*}{ Indirect compound } & \multicolumn{5}{c}{ Treatments } \\
\cline { 2 - 6 } & Control & FA1 & FA2 & FA3 & FA4 \\
\hline $\mathrm{NO}_{2}^{-}$ & $0.11^{\mathrm{b}} \pm 0.0$ & $0.056^{\mathrm{b}} \pm 0.0$ & $0.11^{\mathrm{b}} \pm 0.0$ & $0.11^{\mathrm{b}} \pm 0.0$ & $0.24^{\mathrm{a}} \pm 0.08$ \\
$\mathrm{NO}_{3}{ }^{-}$ & $274.27^{\mathrm{b}} \pm 9.53$ & $265.47^{\mathrm{b}} \pm 8.65$ & $275.01^{\mathrm{b}} \pm 15.18$ & $282.94^{\mathrm{b}} \pm 15.97$ & $386.87^{\mathrm{a}} \pm 12.24$ \\
$\mathrm{SO}_{4}^{--}$ & $479.91^{\mathrm{b}} \pm 11.03$ & $484.39^{\mathrm{b}} \pm 7.29$ & $487.72^{\mathrm{b}} \pm 1.57$ & $516.47^{\mathrm{a}} \pm 9.08$ & $525.53^{\mathrm{a}} \pm 2.51$ \\
\hline
\end{tabular}

Values are the mean \pm SE ${ }^{\mathrm{a}, \mathrm{b}}$ Means within row with different superscripts differ $(\mathrm{p}<0.05)$; Control $=$ Salt media + feces $+1 \%$ soluble starch and FA1-FA4 $=$ Inoculation with $0.1 \mathrm{~g}$ or $\mathrm{ml}$ of different FAs in $100 \mathrm{ml}$ fecal slurry and $1 \mathrm{~g}$ soluble starch; FA1 = Ginseng meal powder; FA2 = Persimmon leaf powder; FA3 = Gingko nut powder; FA4 = Oregano lippia (OL); Unit used for $\mathrm{NO}_{2}, \mathrm{NO}_{3}$ and $\mathrm{SO}_{4}$ content are $\mathrm{mg} / \mathrm{L}$ or ppm; In case of standard and equation used for $\mathrm{NO}_{2}, \mathrm{NO}_{3}$ and $\mathrm{SO}_{4}$ determination were $\mathrm{y}=0.018 \mathrm{x}-0.001\left(\mathrm{R}^{2}=0.994\right), \mathrm{y}=0.005 \mathrm{x}-0.0057\left(\mathrm{R}^{2}=0.9973\right)$, and $\mathrm{y}=0.0032 \mathrm{x}+0.0043\left(\mathrm{R}^{2}=0.9911\right)$, respectively. 
was highest in FA4-group followed by FA3, FA2, Con and FA1 at $24 \mathrm{~h}(\mathrm{p}>0.05)$ (Table 5). The nitrite and nitrate concentration was better in FA4 than the other groups. It is known that ammonia is nitrified by bacterial enzymes to yield nitrite $\left(\mathrm{NO}_{2}\right)$ and nitrate $\left(\mathrm{NO}_{3}\right)$. Bengtson (2010) showed the $\mathrm{NH}_{3}-\mathrm{N}, \mathrm{NO}_{2}$, and $\mathrm{NO}_{3}$ correlation and their conversion by the $\mathrm{N}$-cycle. Therefore, it is considered that conversion of $\mathrm{NO}_{2}$ or $\mathrm{NO}_{3}$ from $\mathrm{NH}_{3}-\mathrm{N}$ is indirectly beneficial for odor reduction during the incubation period. Taken together, these findings indicate that FA4 may facilitate the reduction of nitrogen compounds to $\mathrm{NO}_{2}$ and $\mathrm{NO}_{3}$, thereby reducing odor compounds, though the mechanism is still unknown.

The sulfate concentrations observed at $24 \mathrm{~h}$ of incubation were highest in FA4, followed by FA3, FA2, FA1 and Con $(\mathrm{p}<0.05)$ (Table 5). Hao et al. (1996) reported that sulfur-containing compounds are reduced by bacteria through two processes, reduction of sulfate and metabolism of sulfur-containing amino acids; therefore, higher $\mathrm{SO}_{4}$ production is better in respect of $\mathrm{H}_{2} \mathrm{~S}$ minimization. The results of the present experiment revealed that some of the FA treatments led reduced $\mathrm{H}_{2} \mathrm{~S}$ when compared to the Con at $24 \mathrm{~h}$. This beneficiary affect may have been due to the activation of favorable microbes by using the sulfur for their multiplication and anti microbial action against undesirable microbes to keep the high concentrations sulfate by the applied FAs. Hydrogen sulfide was found to be lower concentrations in some treatments, possibly be due to conversion to other products by the action of beneficial microbes. In addition, Naidu et al. (2002) showed that a novel probiotic effectively reduced sulfur and ammonia compounds in vitro. The results of the present study also showed a reduction trend of $\mathrm{NH}_{3}-\mathrm{N}$ and $\mathrm{H}_{2} \mathrm{~S}$, even though we did not use microbes directly but rather different FAs to modify the microbial environment. Overall, the results presented here confirmed that FA4 produced more sulfate than the other treatments. However, FA4 is suitable for the reduction of $\mathrm{H}_{2} \mathrm{~S}$ by converting it to sulfate, which is the indirect method used to evaluate $\mathrm{H}_{2} \mathrm{~S}$, though the accurate mechanism is still not available.

\section{Effect of FA on dominant bacterial communities during in vitro fermentation}

A representative analysis of the PCR fragments generated with primers 341-GC and 518r and analyzed by DGGE is shown in Figure 1. This gel consisted of DGGE lanes generated from in vitro fermented samples of pig slurry supplemented with soluble starch as a carbohydrate source, four different FAs and the Con. Most of the distinct predominant bands such as 1, 2, 4, 6, 8 and 9 were common to all groups. These bands represented dominant species in the community that were apparently enriched by the carbohydrates and respective FAs. However, DGGE bands

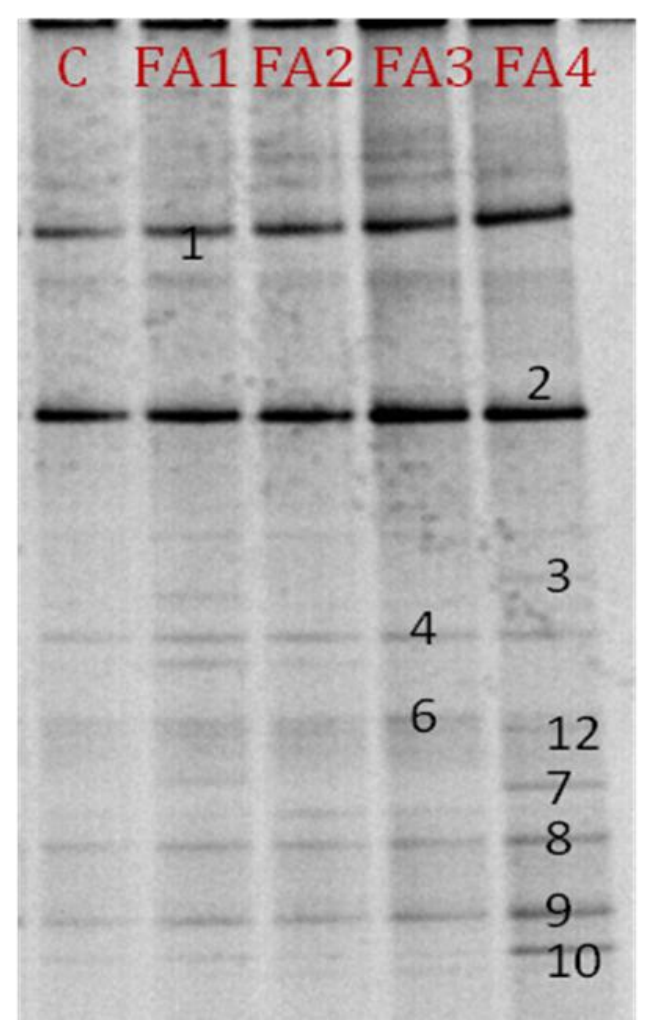

Figure 1. Profile of DGGE bands (1, 2, 3, 4, 6, 7, 8, 9, 10 and 12) generated after PCR amplification of 16SrDNA fragments obtained from treatments composed of different FAs along with soluble starch from $24 \mathrm{~h}$ in vitro fermenta. Lane 1: control; 2: FA1 (ginseng meal powder); 3: FA2 (persimmon leaf powder); 4: FA3 (gingko nut powder); 5: FA4 (oregano lippia) treatments.

$3,7,10$ and 12 were only present in the lanes corresponding to the FA4 group (Figure 1). There is little information available regarding the application of the FA used in this study in conjunction with excess soluble carbohydrates (starch) and their effects on large intestine microbiota. While some of the original bands remained, a few bands also disappeared during the fermentation process, suggesting that they could not use starch as an energy source, or that they represented bacteria that were outcompeted by species better-adapted to utilize FAs.

The similarity indices of the DGGE profiles of the in vitro fermentation samples are presented in Figure 2. There were two clearly different clusters: I (Con, FA1, FA2 and FA3) and II (FA4). The similarity indices of the profiles within these clusters were $100 \%$ and $71 \%$, respectively. The lowest similarity was showed in FA4 among the groups. Overall, the results indicate that FAs created strong selection pressure on the microbial community in vitro. Cluster II (FA4) showed the lowest similarity (71\%), which demonstrated that the different microbial communities of this group differed significantly from that of the other groups. It has been shown that some FA can have a beneficial effect on the host by selectively stimulating the 


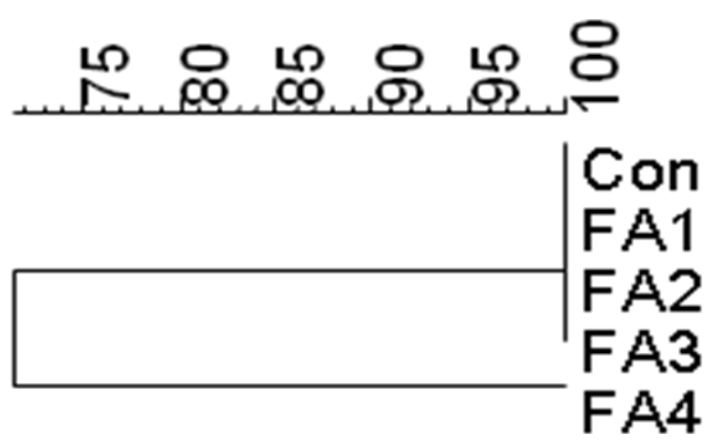

Figure 2. Similarity index of DGGE profiles obtained from $24 \mathrm{~h}$ fecal in vitro fermenta content microflora of pigs using different FAs and soluble starch. Con : control; FA1 : ginseng meal powder; FA2 : persimmon leaf powder; FA3 : gingko nut powder; FA4 : Oregano lippia treatments.

growth and/or activity of one or a limited number of bacteria in the intestine or gut (Tannock, 1999). These results suggest that cluster II had entirely different community structure (bacterial species), which may have facilitated odor reduction. Overall, the two clearly different clusters suggest that the bacterial communities changed with the addition of FAs. These findings are consistent with the concepts of the in vitro fermentation parameters described by Mao et al. (2008). These results also suggest that bacteria originally present on the starch substrate were out-competed by organisms that could use compounds from the specific FA. Overalls, these findings demonstrated that one FA could beneficially affect the host which is similar to the opinion of Tannock (1999).

Ten bands from the V3 region of the DGGE were transformants and were subsequently cloned to confirm the diversified dominant species by supplemented FAs. The bacteria identified from the sequences of each of the bands were distinct, as shown in Table 6 . The sequences for bands 1, 2, 4, 6, 7, 9 and 10 (Figure 1) showed $100 \%$ similarity to their closest relatives (Table 6). The sequences of bands 3, 8 and 12 showed $99 \%, 97 \%$ and $97 \%$ similarity, respectively to their closest relatives (Figure 1) (Table 6). The majority of the dominant bands showed more than $97 \%$ similarity to known sequences in the database. Based on the identical mobility within the gel, common DGGE bands for clones 1, 2, 4, 6, 8 and 9 were present in all of the treatment as well as the Con groups (Figure 1). Bands 3, 7, 10 and 12 were only present in group FA4 (Figure 1), which associated accession numbers were shown in Table 6. Direct sequencing of the excised bands was also conducted to confirm the identity of the bacteria according to the suggestions of Zoetendal et al. (1998), Zhu et al. (2003) and Konstantinov et al. (2003).

The fermentation process had obviously enhanced some bacterial species, and the four distinct strains present in the FA4 fermented group likely modified the fermenta environment in some way, either utilizing or enhancing the odor reducing bacteria. In the present study, the presence of the DGGE bands indicated that the corresponding bacterial species were the predominant bacteria in samples of pigs that received FA4 along with starch. Although the absence of these bands in the other groups could not exclude the presence of the same bacterial species in the sample, it does indicate that these particular bacterial species were not predominant. DGGE and sequencing of their clones in combination with in vitro fermentation was useful to analyze comparisons in the microbial community, which in turn is useful for identifying potential feed ingredients and FAs. Nevertheless, the DGGE results presented in this study suggest that FA may be beneficial for intestinal-gut function and health of pigs by stimulating specific bacteria. Although the dominant bacterial species appears to have been previously identified, their effect on odor causing compounds has not been demonstrated to date. The effect of distinct clones on the odor reduction mechanism is not clear, but the results presented here indicate that these bacteria obviously helped to reduce odor. It is likely that FA provide a subfraction for those bacteria that can utilize the odor compounds, and these odor compound-utilizing bacteria

Table 6. Identification of bands corresponding to bacteria, with percentage of similarity to known sequences in GenBank and sequence length, were retrieved from in vitro fermented pig slurry with feed additives and soluble starch at $24 \mathrm{~h}$

\begin{tabular}{|c|c|c|c|c|}
\hline $\begin{array}{l}\text { Clone } \\
\text { (band no.) }\end{array}$ & Closest relatives & $\begin{array}{c}\text { Sequence similarity } \\
(\%)\end{array}$ & $\begin{array}{l}\text { Sequence length } \\
\text { (bp) }\end{array}$ & Previous isolation \\
\hline 1 & Lactobacillus ultunensis (CCUG 48460T) & 100 & 195 & Chicken crop \\
\hline 2 & Streptococcus macedonicus (ChF-II-str93) & 100 & 196 & Fossa cheese \\
\hline 3 & Eubacterium limosum (ATCC 8486T) & 99 & 172 & Human mouth \\
\hline 4 & Lactobacillus crispatus (DSM 20584T) & 100 & 195 & Chicken crop \\
\hline 6 & Streptococcus alactolyticus (ATCC 43077T) & 100 & 196 & Pig intestine \\
\hline 7 & Lactobacillus amylovorus (DSM 20531T) & 100 & 195 & Chicken crop \\
\hline 8 & Lactobacillus kitasatonis (JCM 1039T) & 97 & 181 & Chicken intestine \\
\hline 9 & Uncultured bacterium clone 20 si 13 & 100 & 170 & GI-tract of pig \\
\hline 10 & Rumen bacterium IVRI-RM-1008 & 100 & 196 & Rumen of goat \\
\hline 12 & Streptococcus lactarius (MV1T) & 97 & 196 & Human milk \\
\hline
\end{tabular}


then accelerate the metabolism of other intermediate products such as $\mathrm{NO}_{3}, \mathrm{NO}_{2}$ and $\mathrm{SO}_{4}$. Therefore, this FA could be associated with the changes in the expected bacteria and activities in their environment. Kim et al. (2008) suggested that this compound (FAs) transforms microbial species related to odor generation in the slurry, possibly due to changes in $\mathrm{pH}$, the characteristics of the substrates and microbial activities. The oregano lippia (OL) of the present experiment seems to be function similarly.

The OL treatment resulted in the lowest generation of odor compounds such as $\mathrm{NH}_{3}-\mathrm{N}, \mathrm{H}_{2} \mathrm{~S}$ and VFAs, and comparatively a higher level of intermediate $\left(\mathrm{NO}_{2}, \mathrm{NO}_{3}\right.$ and $\mathrm{SO}_{4}$ ) during in vitro fermentation, as well as more bacterial communities (DGGE) when compared to other treatments. These findings indicate that the use of oregano as a FA may reduce the odor produced by growing pigs during carbohydrate loading in the large intestine.

\section{ACKNOWLEDGEMENT}

This work was carried out with the support of "Cooperative Research Program for Agriculture Science and Technology Development (Project No. PJ0074512012)" Rural Development Administration, Republic of Korea and by the Technology Development Program for Agriculture and Forestry, Ministry of Agriculture, Forestry and Fisheries, Republic of Korea, 2102. The project was titled as "Development of production technologies for high quality of beef in Hanwoo".

\section{REFERENCES}

Aarnink, A. J. A., P. Le Dinh, N. W. M. Ogink, P. M. Becker and M. W. A. Verstegen. 2005. Odour from animal production facilities: its relationship to diet. Nutr. Res. Rev. 18:3-30.

Amon, M., T. H. Misselbrook, B. F. Pain, V. R. Phillips and R. W. Sneath. 1995. A farm scale study on the use of de-odorase for reducing odour and ammonia emissions from intensive fattening piggeries. Bioresour. Technol. 51:163-169.

Bailey, S. R., A. Rycroft and J. Elliott. 2002. Production of amines in equine cecal contents in an in vitro model of carbohydrate overload. J. Anim. Sci. 80:2656-2662.

Bengtson, H. 2010. Easy to understand diagram of nutrient cycle.

Chaney, A. L. and E. P. Marbach. 1962. Modified reagents for determination of urea and ammonia. Clin. Chem. 8:130-132.

Colina, J. J., A. J. Lewis, P. S. Miller and R. L. Fischer. 2001. Dietary manipulation to reduce aerial ammonia concentrations in nursery pig facilities. J. Anim. Sci. 79:3096-3103.

Cromwell, G. L. 1998. Manipulation of swine diets to reduce odors and harmful gaseous emissions from manure. University of Kentucky.

Cummings, J. H. and G. T. Macfarlane. 1991. The control and consequences of bacterial fermentation in the human colon. J. Appl. Microbiol. 70:443-459.

Denaturing Gradient Gel Electrophoresis (DGGE). 2004. Online. Available: http://www.eeescience.utoledo.edu/Faculty/Sigler/
Von_Sigler/LEPR_Protocols_files/DGGE.pdf.

Fakhoury, K. J., A. J. Heber, P. Shao and J. Q. Ni. 2000. Correlation of odor detection thresholds with concentrations of hydrogen sulfide, ammonia and trace gases emitted from swine manure. Pages 1-13. American Society of Agricultural Engineers, St Joseph.

Felske, A., A. Wolterink, R. Van Lis and A. D. L. Akkermans. 1998. Phylogeny of the main bacterial 16S rRNA sequences in drentse a grassland soils (The Netherlands). Appl. Environ. Microbiol. 64:871-879.

Gibson, G. R., J. H. Cummings and G. T. Macfarlane. 1988. Competition for hydrogen between sulphate-reducing bacteria and methanogenic bacteria from the human large intestine. J. Appl. Microbiol. 65:241-247.

Han, S.-K., S.-H. Kim and H.-S. Shin. 2005. UASB treatment of wastewater with VFA and alcohol generated during hydrogen fermentation of food waste. Process Biochem. 40:2897-2905.

Häne, B. G., K. Jäger and H. G. Drexler. 1993. The pearson product-moment correlation coefficient is better suited for identification of DNA fingerprint profiles than band matching algorithms. Electrophoresis 14:967-972.

Hao, O. J., J. M. Chen, L. Huang and R. L. Buglass. 1996. Sulfatereducing bacteria. Crit. Rev. Environ. Sci. Technol. 26:155-187.

Hayes, E. T., A. B. G. Leek, T. P. Curran, V. A. Dodd, O. T. Carton, V. E. Beattie and J. V. O'Doherty. 2004. The influence of diet crude protein level on odour and ammonia emissions from finishing pig houses. Bioresour. Technol. 91:309-315.

Hume, M. E., S. Clemente-Hernández and E. O. Oviedo-Rondón. 2006. Effects of feed additives and mixed eimeria species infection on intestinal microbial ecology of broilers. Poult. Sci. 85:2106-2111.

Jenkins, D. and L. L. Medsker. 1964. Brucine method for the determination of nitrate in ocean, estuarine, and fresh waters. Anal. Chem. 36:610-612.

Jensen, M. T., R. P. Cox and B. B. Jensen. 1995. Microbial production of skatole in the hind gut of pigs given different diets and its relation to skatole deposition in backfat. Anim. Sci. 61:293-304.

Jensen, M. T. and L. L. Hansen. 2006. Feeding with chicory roots reduces the amount of odorous compounds in colon and rectal contents of pigs. Anim. Sci. 82:369-376.

Killeen, G. F., C. R. Connolly, G. A. Walsh, C. F. Duffy, D. R. Headon and R. F. Power. 1998. The effects of dietary supplementation with Yucca schidigera extract or fractions thereof on nitrogen metabolism and gastrointestinal fermentation processes in the rat. J. Sci. Food Agric. 76:91-99.

Kim, K.-Y., H.-J. Ko, H.-T. Kim, Y.-S. Kim, Y.-M. Roh, C.-M. Lee and C.-N. Kim. 2008. Odor reduction rate in the confinement pig building by spraying various additives. Bioresour. Technol. 99:8464-8469.

Kolmert, Å., P. Wikström and K. B. Hallberg. 2000. A fast and simple turbidimetric method for the determination of sulfate in sulfate-reducing bacterial cultures. J. Microbiol. Methods 41:179-184.

Konstantinov, S. R., F. F. Christine, Z. Wei Yun, A. W. Barbara, K. Jeannette, S. Wolfgang-Bernhard, M. D. V. Willem, D. L. A. Antoon and S. Hauke. 2004. Microbial diversity studies of the porcine gastrointestinal ecosystem during weaning transition. Anim. Res. 53:317-324. 
Konstantinov, S. R., W.-Y. Zhu, B. A. Williams, S. Tamminga, W. M. de Vos and A. D. L. Akkermans. 2003. Effect of fermentable carbohydrates on piglet faecal bacterial communities as revealed by denaturing gradient gel electrophoresis analysis of $16 \mathrm{~S}$ ribosomal DNA. FEMS Microbiol. Ecol. 43:225-235.

Le, P. D., A. J. A. Aarnink and A. W. Jongbloed. 2009. Odour and ammonia emission from pig manure as affected by dietary crude protein level. Livest. Sci. 121:267-274.

Le, P. D., A. J. A. Aarnink, A. W. Jongbloed, C. M. C. V. d. PeetSchwering, N. W. M. Ogink and M. W. A. Verstegen. 2007. Effects of dietary crude protein level on odour from pig manure. Animal 1:734-744.

Mackie, R. I., P. G. Stroot and V. H. Varel. 1998. Biochemical identification and biological origin of key odor components in livestock waste. J. Anim. Sci. 76:1331-1342.

Mao, S. Y., G. Zhang and W. Y. Zhu. 2008. Effect of disodium fumarate on ruminal metabolism and rumen bacterial communities as revealed by denaturing gradient gel electrophoresis analysis of $16 \mathrm{~S}$ ribosomal DNA. Anim. Feed Sci. Technol. 140:293-306.

Miner, J. R. 1977. Characterization of odors and other volatile emissions. Agric. Environ. 3:129-137.

Morrison, T. B., J. J. Weis and C. T. Wittwer. 1998. Quantification of low-copy transcripts by continuous SYBR Green I monitoring during amplification. Biotechniques 24:954-958, 960, 962.

Muyzer, G., E. C. de Waal and A. G. Uitterlinden. 1993. Profiling of complex microbial populations by denaturing gradient gel electrophoresis analysis of polymerase chain reactionamplified genes coding for $16 \mathrm{~S}$ rRNA. Appl. Environ. Microbiol. 59:695-700.

Muyzer, G. and K. Smalla. 1998. Application of denaturing gradient gel electrophoresis (DGGE) and temperature gradient gel electrophoresis (TGGE) in microbial ecology. Antonie van Leeuwenhoek 73:127-141.

Naidu, A. S., X. Xie, D. A. Leumer, S. Harrison, M. J. Burrill and E. A. Fonda. 2002. Reduction of sulfide, ammonia compound, and adhesion properties of Lactobacillus casei strain KE99 in vitro. Curr. Microbiol. 44:196-205.

Nübel, U., B. Engelen, A. Felske, J. Snaidr, A. Wieshuber, R. I. Amann, W. Ludwig and H. Backhaus. 1996. Sequence heterogeneities of genes encoding 16S rRNAs in Paenibacillus polymyxa detected by temperature gradient gel electrophoresis. J. Bacteriol. 178:5636-5643.

Nyachoti, C. M., F. O. Omogbenigun, M. Rademacher and G Blank. 2006. Performance responses and indicators of gastrointestinal health in early-weaned pigs fed low-protein amino acid-supplemented diets. J. Anim. Sci. 84:125-134.

O'Connell, J. M., T. Sweeney, J. J. Callan and J. V. O'Doherty. 2005. The effect of cereal type and exogenous enzyme supplementation in pig diets on nutrient digestibility, intestinal microflora, volatile fatty acid concentration and manure ammonia emissions from finisher pigs. Anim. Sci. 81:357-364.
Oviedo-Rondón, E. O. 2009. Molecular methods to evaluate effects of feed additives and nutrients in poultry gut microflora Revista Brasileira de Zootecnia 38:209-225.

Parker, J., E. O. Oviedo-Rondón, B. A. Clack, S. ClementeHernández, J. Osborne, J. C. Remus, H. Kettunen, H. Mäkivuokko and E. M. Pierson. 2007. Enzymes as feed additive to aid in responses against eimeria species in coccidiavaccinated broilers fed corn-soybean meal diets with different protein levels. Poult. Sci. 86:643-653.

Patra, A. K., D. N. Kamra and N. Agarwal. 2006. Effect of spices on rumen fermentation, methanogenesis and protozoa counts in in vitro gas production test. Int. Congr. Ser. 1293:176-179.

Rainville, N. and A. Morin. 1985. Change in the volatile fatty acids content of laboratory stored sterilized and non-sterilized swine wastes. Microbios 42:175-182.

Ritter, W. F. 1989. Odour control of livestock wastes: State-of-theart in North America. J. Agric. Eng. Res. 42:51-62.

Robinson, J. A., W. J. Smolenski, M. L. Ogilvie and J. P. Peters. 1989. In vitro total-gas, $\mathrm{CH}_{4}, \mathrm{H}_{2}$, volatile fatty acid, and lactate kinetics studies on luminal contents from the small intestine, cecum, and colon of the pig. Appl. Environ. Microbiol. 55:2460-2467.

SAS. 2002. SAS/STAT. Statistical Analysis Systems for Windows release 9.1. SAS Institute Inc., Cary, NC, USA

Tabaru, H., E. Kadota, H. Yamada, N. Sasaki and A. Takeuchi. 1988. Determination of volatile fatty acids and lactic acid in bovine plasma and ruminal fluid by high performance liquid chromatography. Japanese J. Vet. Sci. 50:1124-1126.

Tannock, G. W. 1999. Probiotics: a critical review. Prebiotics. Horizon Scientific Press.

van Beers-Schreurs, H. M. G., M. J. A. Nabuurs, L. Vellenga, H. J. K.-v. d. Valk, T. Wensing and H. J. Breukink. 1998. Weaning and the weanling diet influence the villous height and crypt depth in the small intestine of pigs and alter the concentrations of short-chain fatty acids in the large intestine and bood. J. Nutr. 128:947-953.

Wang, J. F., Y. H. Zhu, D. F. Li, Z. Wang and B. B. Jensen. 2004. In vitro fermentation of various fiber and starch sources by pig fecal inocula. J. Anim. Sci. 82:2615-2622.

Windisch, W., K. Schedle, C. Plitzner and A. Kroismayr. 2008. Use of phytogenic products as feed additives for swine and poultry. J. Anim. Sci. 86(14 Suppl):E140-E148.

Zhu, J. 2000. A review of microbiology in swine manure odor control. Agric. Ecosyst. Environ. 78:93-106.

Zhu, W.-Y., B. A. Williams, S. R. Konstantinov, S. Tamminga, W. M. De Vos and A. D. L. Akkermans. 2003. Analysis of 16S rDNA reveals bacterial shift during in vitro fermentation of fermentable carbohydrate using piglet faeces as inoculum. Anaerobe 9:175-180.

Zoetendal, E. G., A. D. L. Akkermans and W. M. De Vos. 1998. Temperature gradient gel electrophoresis analysis of $16 \mathrm{~S}$ rRNA from human fecal samples reveals stable and host-specific communities of active bacteria. Appl. Environ. Microbiol. 64:3854-3859. 